\section{International conference of the Inflammation Research Association}

Second notice of the 5th international conference of the Inflammation Research Association. This will be held from 23 to 27 September 1990, at the Mountain Laurel Resort and Conference Center, White Haven, Pennsylvania, USA.

The symposium topics will be antiarthritic drugs, cytokines, regulation of leucocyte functions in inflammation, and tissue destruction.

For further information contact the registrar: Dr Joan Chapdelaine, IRA Conference, Pharmakon Research International Inc, PO Box 313, Waverly, PA 18471, USA. Tel (717) 586 2411. Fax (717) 5863450.

\section{International conference on SLE}

A preliminary announcement of the IIIrd international conference on SLE, which will be held in the Queen Elizabeth II Conference Centre, Westminster, London, on 13, 14, and 15 April 1992.

For further details please contact Dr Graham Hughes or Mrs Denzil Fletcher, Rheumatology Department, St Thomas's Hospital, London SE1 7EH. Tel and Fax (071) 6339422.

\section{Rehabilitation aids for handicapped persons}

This international exhibition, REHA 91, will take place at the Dusseldorf Trade Fair complex between 23 and 27 October 1991. The Federal Congress for Rehabilitation will take place in Dusseldorf parallel to REHA 91 over the same dates. The new president of this congress is Hubertus Stroebel, director of the Federal Association for Rehabilitation (BAR), Frankfurt, and vice-president of Rehabilitation International.

The REHA 89 congress report, published in German and English, at a cost of DM 25.00 inclusive of postage and packing will be available from Helga Liesegang at Messe Dusseldorf, Congress Organisation Department. Tel 02114560984.

For further details of REHA 91 contact Eva Rugenstein, REHA 91 Press Office, Dusseldorfer, Messegeseilschaft mbH-NOWEA-Postfach 320203 , Stockumer Kirchstrade 61, D-4000 Dusseldorf 30. Tel (0211) 4560996 and (0211) 456 0541

\section{Educational visits to UK rheumatology centres}

As a trainee in rheumatology (registrar, senior registrar, or equivalent) you may wish to broaden your experience by visiting other rheumatology units. Many centres around the United Kingdom are willing to host such visits. Details of these rheumatology units are available from the British Society for Rheumatology, and the organisation of the visit is then up to the visitor. Doctors from both the United Kingdom and overseas are welcome to contact the British Society. for Rheumatology for further details: UK Rheumatology Visits, British Society for Rheumatology, 3 St Andrew's Place, Regent's Park, London NW1 4LE.

\section{Calendar of events}

In 1990

25-27 June

Osteoporosis and bone mineral measurement Contact: The National Osteoporosis Society, PO Box 10, Radstock, Bath BA3 3YB. Tel 076132472

26-30 June 2nd International congress of the International Society for Rheumatic Therapy, London Contact: Paul Turner, ISRT Secretariat, Pinewood Studios, Iver Heath, Bucks SL0 0NH. Tel 753 656706. Fax 753656169 , or Dr A Calin, Royal National Hospital for the Rheumatic Diseases, Bath BA1 1RL. Tel 0225 465941

19-20 July Research in arthritis. The Mathilda and Terence Kennedy Institute of Rheumatology, 25th anniversary symposium. The Royal Society, London W1

Contact: Mr C Boden, General Secretary, The Kennedy Institute of Rheumatology, 6 Bute Gardens, Hammersmith, London W6 7DW. Tel 0817489966 (Ext 4002)

19-22 July

3rd European congress-'Back pain: current concepts and recent advances', Glasgow, Scotland

Contact: Secretariat, Congress Team International (UK) Ltd, 30 Deane Way, Ruislip, Middlesex, England. Tel 0812060426 . Telex 892486

6-7 Sept 8th Annual inflammation meeting, Birmingham, 1990

Contact: Petra Hickey, Symposium Secretary, Rheumatism Research Wing, The Medica School, Birmingham B15 2TJ

12-14 Sept 18th Osteoarthrology symposium, Dubrovnik, Yugoslavia

Contact: Professor Ivo Jajic, President of Organizing Committee, Lovcenska 100, 41000 Zagreb, Yugoslavia

13-15 Sept 7th Symposium of the Primary Care Rheumatology Society, University of Keele, Stoke-onTrent

Contact: Ms Helen Livesley, PCR, 55 South Parade, Northallerton, North Yorkshire DL7 8SL. Tel 0609774794

16-19 Sept

First European conference on the epidemiology of rheumatic diseases

Contact: Professor Ivo Jajic, Croatian Medical Association, Rheumatological Section, Vinogradska 29, 41000 Zagreb, Yugoslavia

29 Oct-3 Nov American College of Rheumatology meeting, Seattle

15-16 Nov BSR rehabilitation course

Contact: Dr A O Frank, Northwick Park Hospital, Watford Road, Harrow, Middlesex HAl 3UJ 
15-17 Nov European conference on systemic lupus erythematosus, Amsterdam, The Netherlands Contact: Conference Secretariat, IMEDEX, Bruistensingel 144, PO Box 3283, NL-5203 DG's Hertogenbosch, The Netherlands. Tel 3173408 304. Telefax 3173408304

In 1991

12 Apr

BSR Spring Meeting, Oxford

Contact: Dr A Mowat, Heberden Roundsman

30 June-6 July XIIth European congress on rheumatology, Budapest, Hungary
18-20 Sept 8th BSR annual general meeting, Imperial College, London

\section{In 1992}

13-15 Apr

3rd International conference on systemic lupus erythematosus, Queen Elizabeth 2nd Conference Centre, Westminster, London

Contact: Dr G R V Hughes, Rayne Institute, St Thomas's Hospital, London SEl 7EH. Tel 0716339422

\section{Book reviews}

Osteoporosis: Prevention, Management, Treatment. H H McIlwain, D F Bruce, J C Silverfield, M C Burnette. (Pp 150 ; \$9.95.) New York: Wiley, 1988. ISBN 0-471-61688-5.

This is a handbook for patients, actual and potential, and for all lay readers with an interest in osteoporosis. It is written jointly by three American doctors, one a specialist, who share a Florida practice, and by one professional writer. Within its context it provides a comprehensive account of osteoporosis-what it is, how it should be managed, its risk factors, signs and symptoms, and plans for prevention and treatment from childhood to old age. It is profusely but clearly illustrated, readable, and informative.

It might be argued that the benefits of high calcium intake and calcium supplementation are less well proved than the authors uncritically maintain. The minute details given of the calcium content of everything we eat might, therefore, lead to unnecessary obsessions on the patients' part.

Nevertheless, the book is judicious in its recommendations for therapy and treads a fair line between accepted and experimental treatment. Other details include a simple description of quantitative computed tomography and even the exact calcium content of every 'dish' available at McDonalds and Burger King! The flavour is therefore transatlantic, and one disadvantage to British readers is the limitation of all drug names to American proprietary preparations. Despite this, it may be the best paperback handbook on the subject to date and can be recommended to all interested lay readers and other health care groups in nursing, physiotherapy, and dietetics.

Royal National Orthopaedic Hospital, 234 Great Portland Street,

London $W I$

T C B STAMP

Acupuncture, Trigger Points and Musculoskeletal Pain. P E Baldry. (Pp 308; £27.50.) Edinburgh: Churchill Livingstone, 1988. ISBN 0443-039-917.

Dr Baldry, a consultant physician and past chairman of the British Medical Acupuncture Society, has written an excellent book on this often neglected area.

He gives a clear account of musculoskeletal pain and its relation to trigger points. These points often at a distance from the site of the pain may be treated by the insertion of acupuncture needles. The author's stated aim is to take acupuncture out of the category of alternative medicine, and I believe he has succeeded in writing a book which will be of interest to many.

The book is divided into three parts. The first gives an interesting short account of the development of acupuncture in China and its subsequent use in Europe from the 17th century. The second part discusses the basic principles of trigger point acupuncture. This section also includes a chapter on the scientific evaluation of acupuncture with a summary of relevant trials and useful chapters on the neurophysiology of pain and the pain suppressing effects of acupuncture. Areas of future research are suggested.

The third section of the book is an extensive practical manual based on the personal experience of the author. This section, as are the others, is clearly written and gives his approval to diagnosis and treatment together with appropriate case histories. Each chapter is well illustrated with clear anatomical drawings and pain referral patterns from trigger points. There is an up to date list of references at the end of every chapter.

Department of Rheumatology,

B HAZLEMAN

Addenbrooke's Hospital,

Hills Road,

Cambridge CB2 $2 Q Q$

The Colour Atlas of Bone Disease. Victor Parsons. (Pp 112; £14.95, paperback.) London: Wolfe Medical, 1989. ISBN 0-7234-1602-8.

This is a paperback edition of a volume first published in 1980 and unfortunately not revised. It has some very beautiful illustrations which show (most often) the clinical appearances of the disease backed up by histological examination of the tissues where appropriate. As an atlas it therefore achieves its purpose.

The introduction, quite rightly, mentions the importance of a dietary history and includes tables of foods with high calcium, phosphate, vitamin $\mathrm{D}$, and vitamin $\mathrm{C}$ content. The illustrations which accompany these tables are in an appendix at the end of the book which serves no useful purpose. It consists of four pictures of $100 \mathrm{~g}$ portions of food items such as bread, sardines, and milk which, even if you did not know what sardines look like, are of such poor quality as to be of no help.

The section on osteoporosis describes use of the Singh index of femoral trabecular patterns for the diagnosis of osteoporosis. Unfortunately, no mention is made of the newer and more reliable techniques for measuring bone density. When vitamin $\mathrm{D}$ physiology is discussed the active metabolite of vitamin $\mathrm{D}$, 1,25-dihydroxycholecalciferol, is incorrectly referred to as 1,25 $\mathrm{OHCC}$ when it should be $1,25(\mathrm{OH})_{2} \mathrm{CC}$, an error which should not be present in a book dealing with bone diseases.

The section on the microscopic structure of bone is beautifully illustrated and describes clearly the events in bone remodelling. There is no mention made, however, of the role of growth factors and cytokines in bone cell physiology. Such an omission clearly indicates the need for a new, revised edition. In the chapter on 'Bone involvement in system disease' conditions such as achondroplasia and osteogenesis imperfecta are illustrated but there are no diagrams for the various mucopolysaccharidoses. A subsection in this chapter deals with bone disease accompanying inflammatory joint disease. There is a brief mention of rheumatoid arthritis with appropriate 